\title{
THIRTIETH INTERNATIONAL CONGRESS OF HUMAN SCIENCES IN ASIA AND NORTH AFRICA
}

\author{
Formerly The International Congress of Orientalists
}

MEXICO CITY, AUGUST 3-8, 1976

El Colegio de México will serve as host for the Thirtieth International Congress of Human Sciences in Asia and North Africa, as the International Congress of Orientalists is now known. The Congress, to be held in Mexico City August 3-8, 1976, will be the first to have met in Latin America. The President of the Congress is Professor Graciela De la Lama, the Secretary General is Professor Jorge Alberto Lozoya, and the Adjunct Secretary is Dr. Manuel Ruiz.

History, sociology, economics, philosophy, art, literature, anthropology, and contemporary problems of Asia and North Africa will be among the main fields represented in the Congress. The program will be divided into sections, seminars, colloquia, and conferences. Sections will be divided into: (1) West Asia and North Africa, (2) Central and Northern Asia, (3) South Asia, (4) Southeast Asia, and (5) East Asia, (a) China, and (b) Japan and Korea.

The deadline for submitting titles for the Congress program is January 1, 1976. Summaries of not more than 200 words are due before April 1. Papers should not be longer than 15-20 minutes. The official languages of the Congress are Spanish, English, and French. All communications should be addressed to:

\author{
The Secretary General \\ 30 International Congress of Human \\ Sciences in Asia and North Africa \\ El Colegio de México \\ Guanajuato 125 \\ México 7, D.F., MEXICO
}




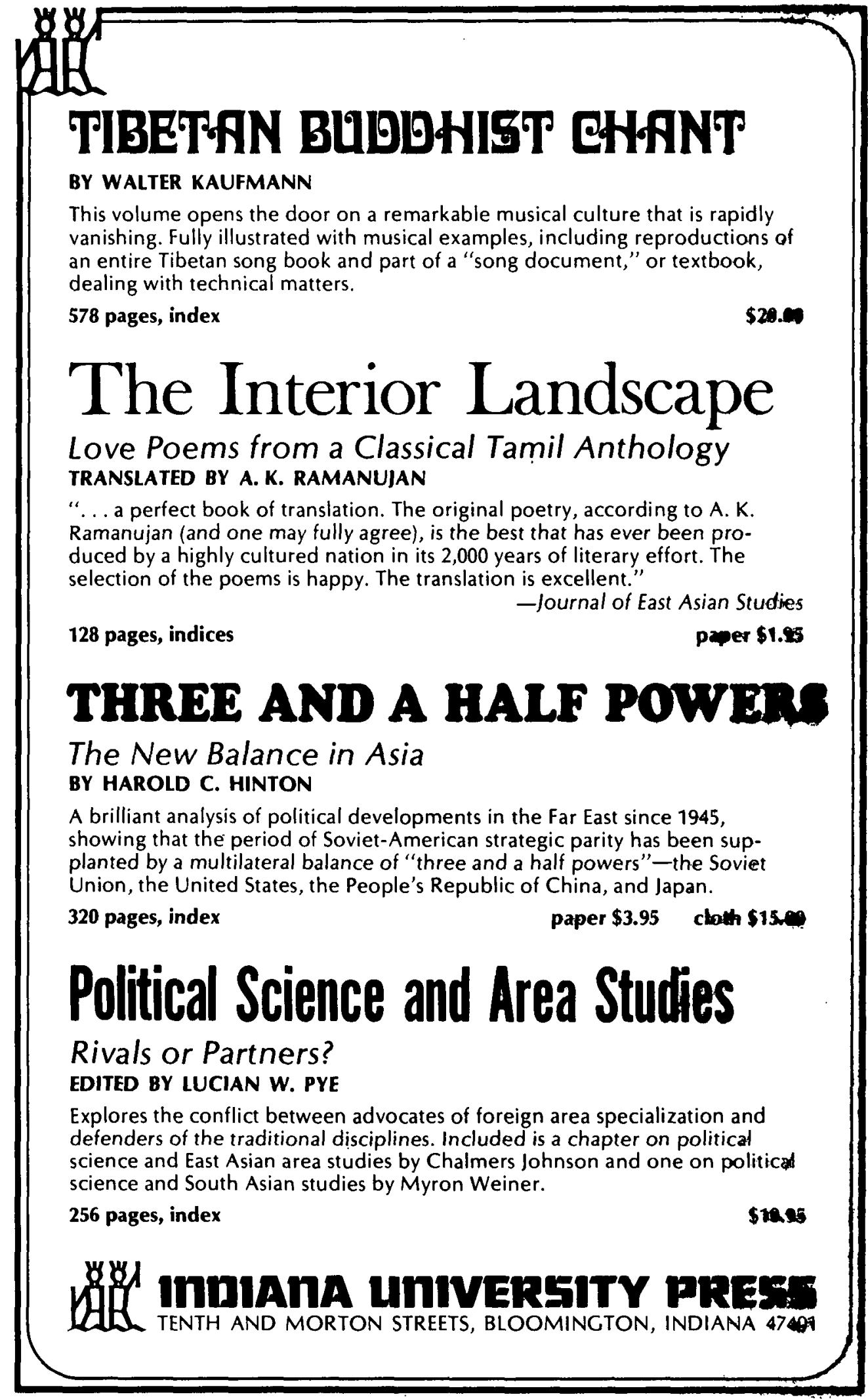




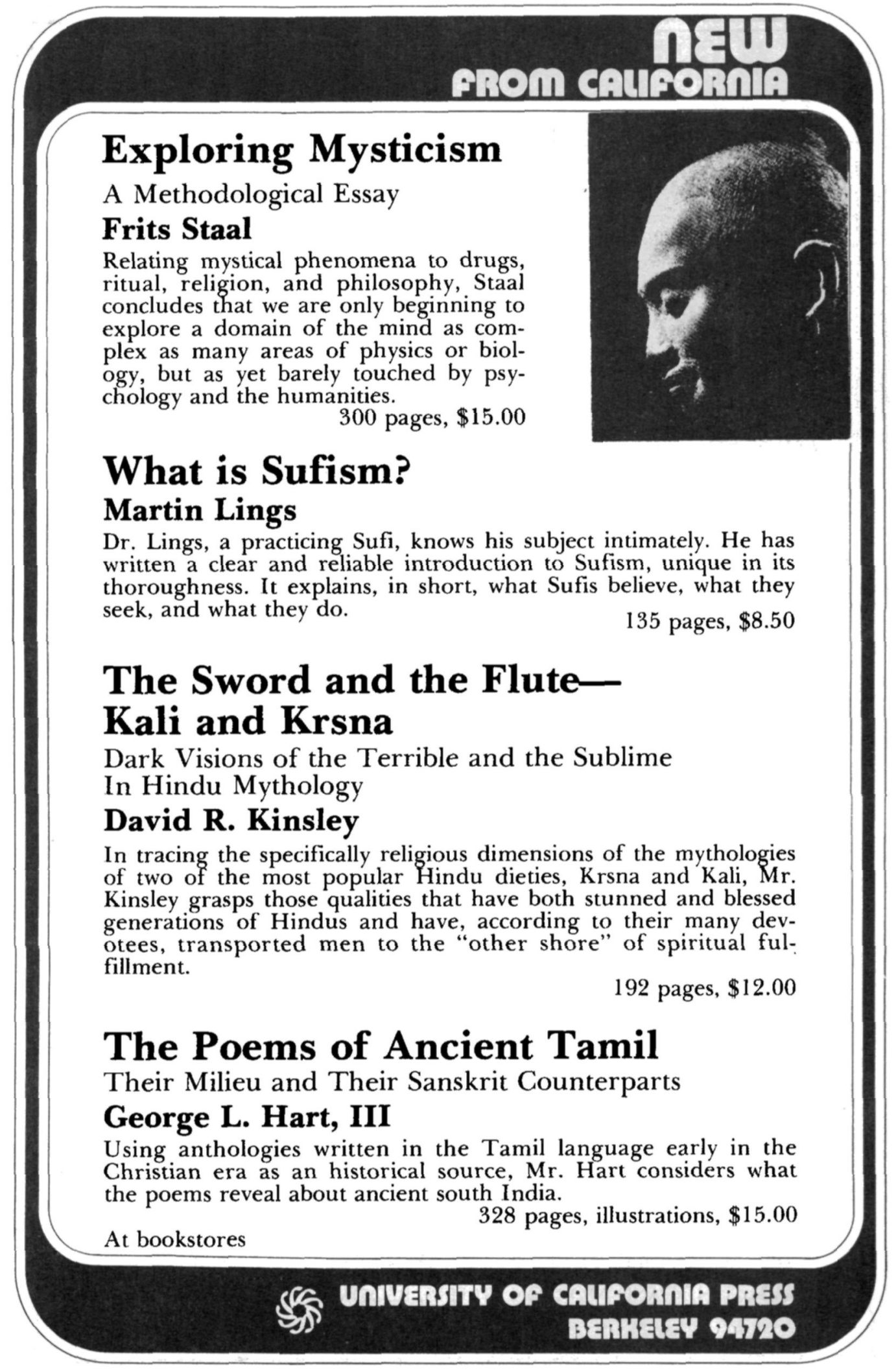




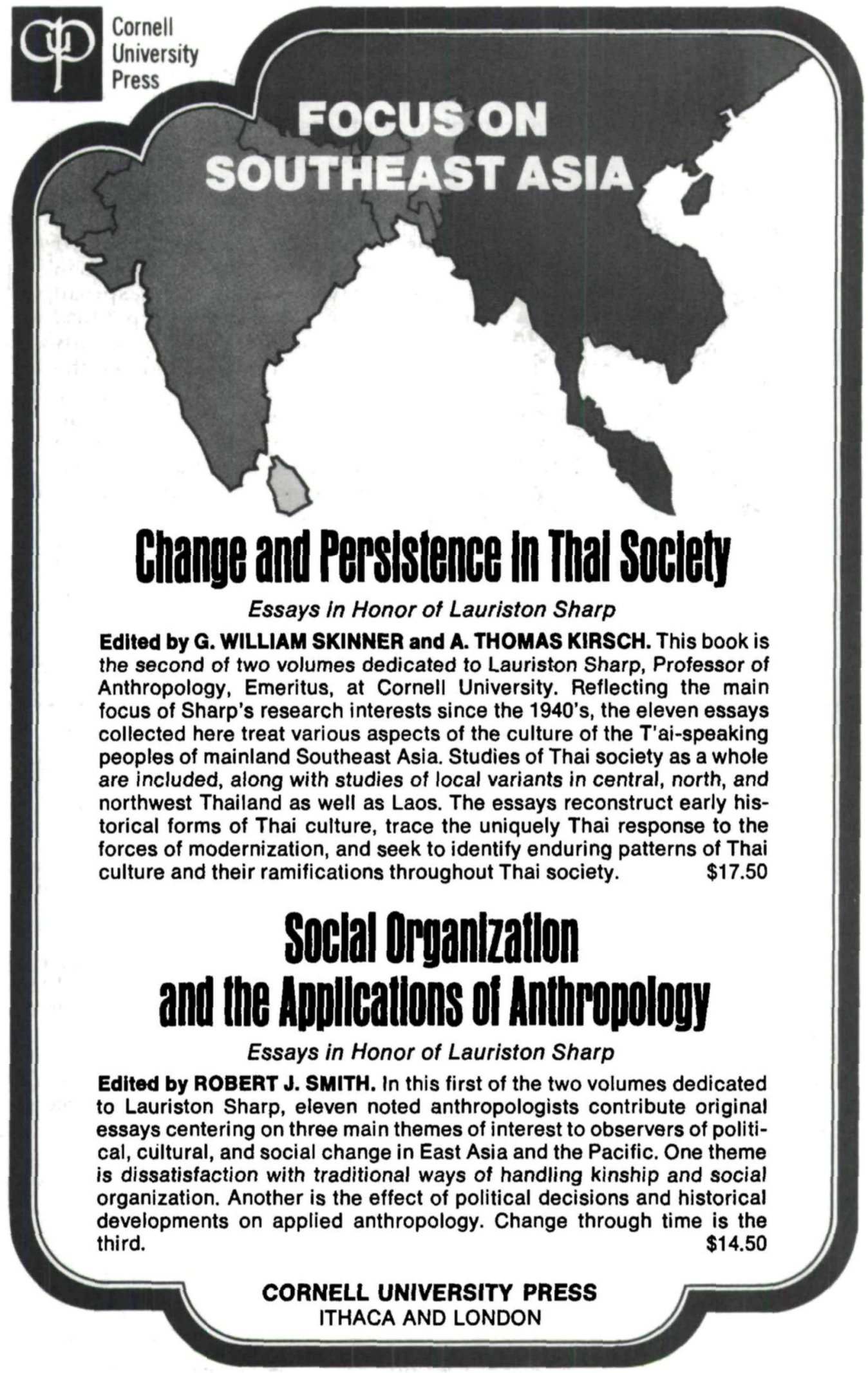




\section{PEASANT SOCIETY IN A CHANGING ECONOMY}

\section{Comparative Development in Southeast Asia and India}

GEORGE ROSEN

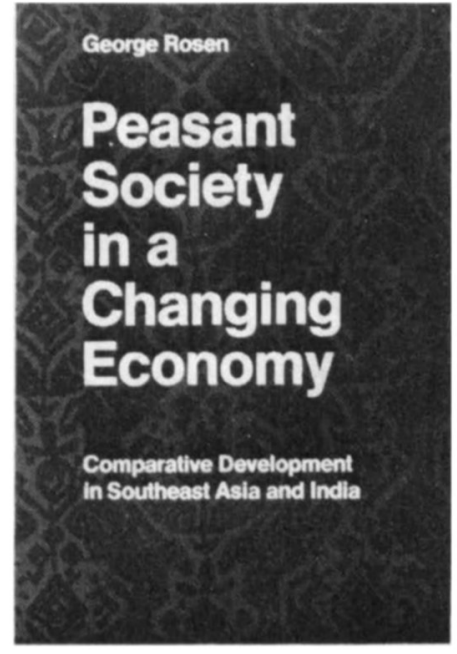

Stressing the possibility of revolution in the Philippines, Indonesia, and Thailand - unless significant change in their governments occurs - George Rosen suggests ways to avoid widespread human misery and social and political instability in Southeast Asia. In this interdisciplinary study, he relates the process of social and political change to that of economic development and compares the experiences of these three countries with those of India.". . . embodies wide-ranging and imaginative scholarship on a series of very significant problems." - Milton J. Esman, Center for International Studies at Cornell University. 269 pages. $\$ 8.95$

UNIVERSITY OF ILLINOIS PRESS $\Phi$ URBANA 61801

\section{ASIAN SURVEY}

Leading American monthly devoted to current developments in Asia. Coverage of political, economic and social trends in such societies as China, India, Japan, Pakistan, Korea, Indonesia, Thailand and Burma.

As an annual feature, two structured issues are published in January and February surveying major trends for the previous year in twenty-one Asian countries. The other ten issues include articles on a wide range of contemporary developments in East and Southern Asia as well as occasional structured symposia.

Rates: In the U.S., Canada, and Latin America, $\$ 15.00$ a year for individuals, $\$ 21.00$ for institutions, $\$ 9.00$ for students; elsewhere, $\$ 16.00$ a year for individuals, $\$ 22.00$ for institutions, $\$ 10.00$ for students. 


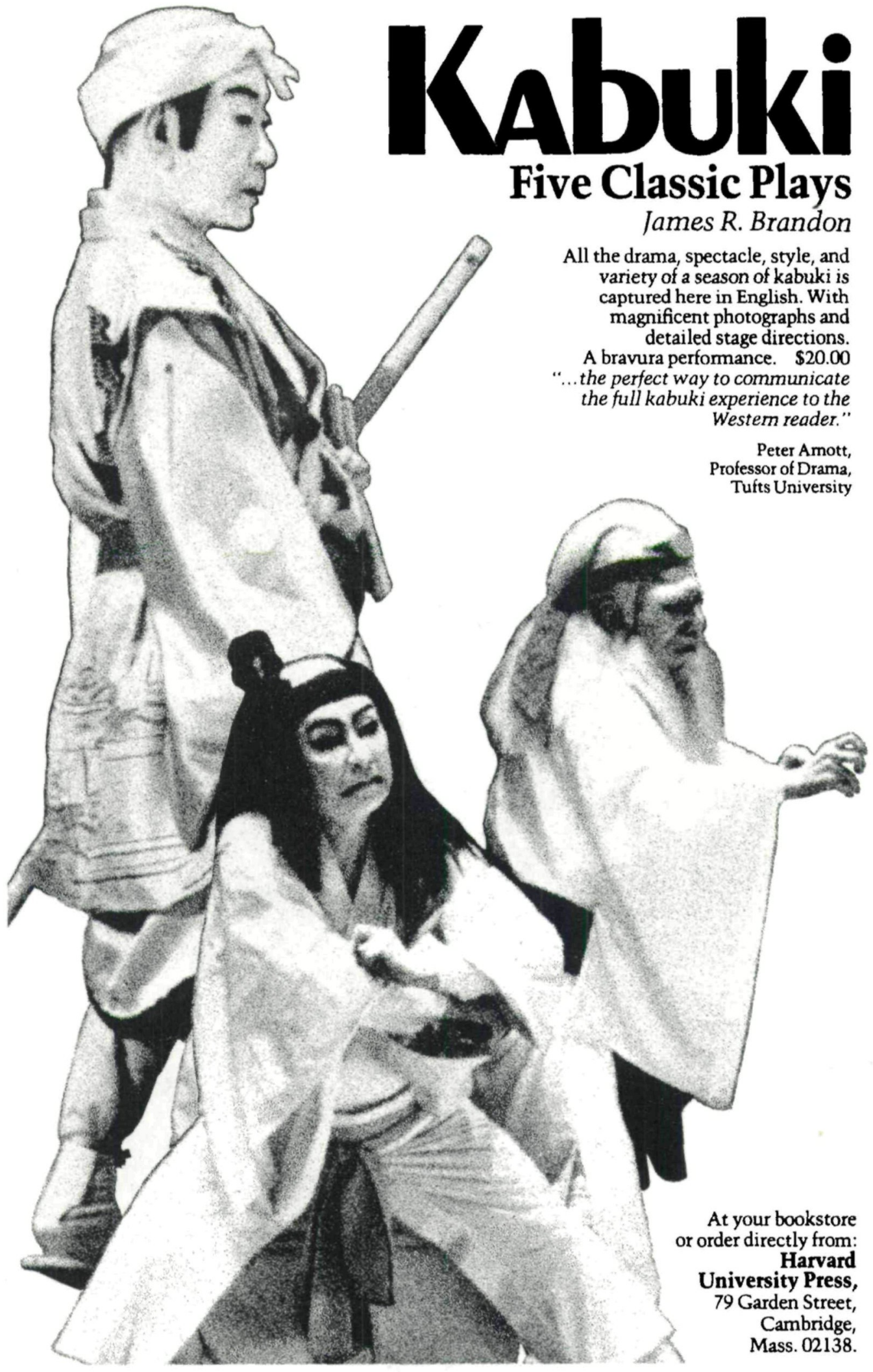




\section{AAS REPRINT SERIES}

\section{MARKETING AND SOCIAL STRUCTURE IN RURAL CHINA PARTS I-III}

\section{BY G. WILLIAM SKINNER}

Reprinted from THE JOURNAL OF ASIAN STUDIES, the three articles are now available as a unit.

Price: $\$ 1.50 /$ copy

PREPAID ORDERS should be sent to:

Association for Asian Studies Inc.

1 Lane Hall, University of Michigan

Ann Arbor, Michigan 48104

Please send copy(ies) at $\$ 1.50 /$ copy of MARKETING AND

SOCIAL STRUCTURE IN RURAL CHINA by G. William Skinner.

NAME:

ADDRESS:

(Zip Coder)

ORDERS MUST BE PREPAID: Amount Enclosed: 

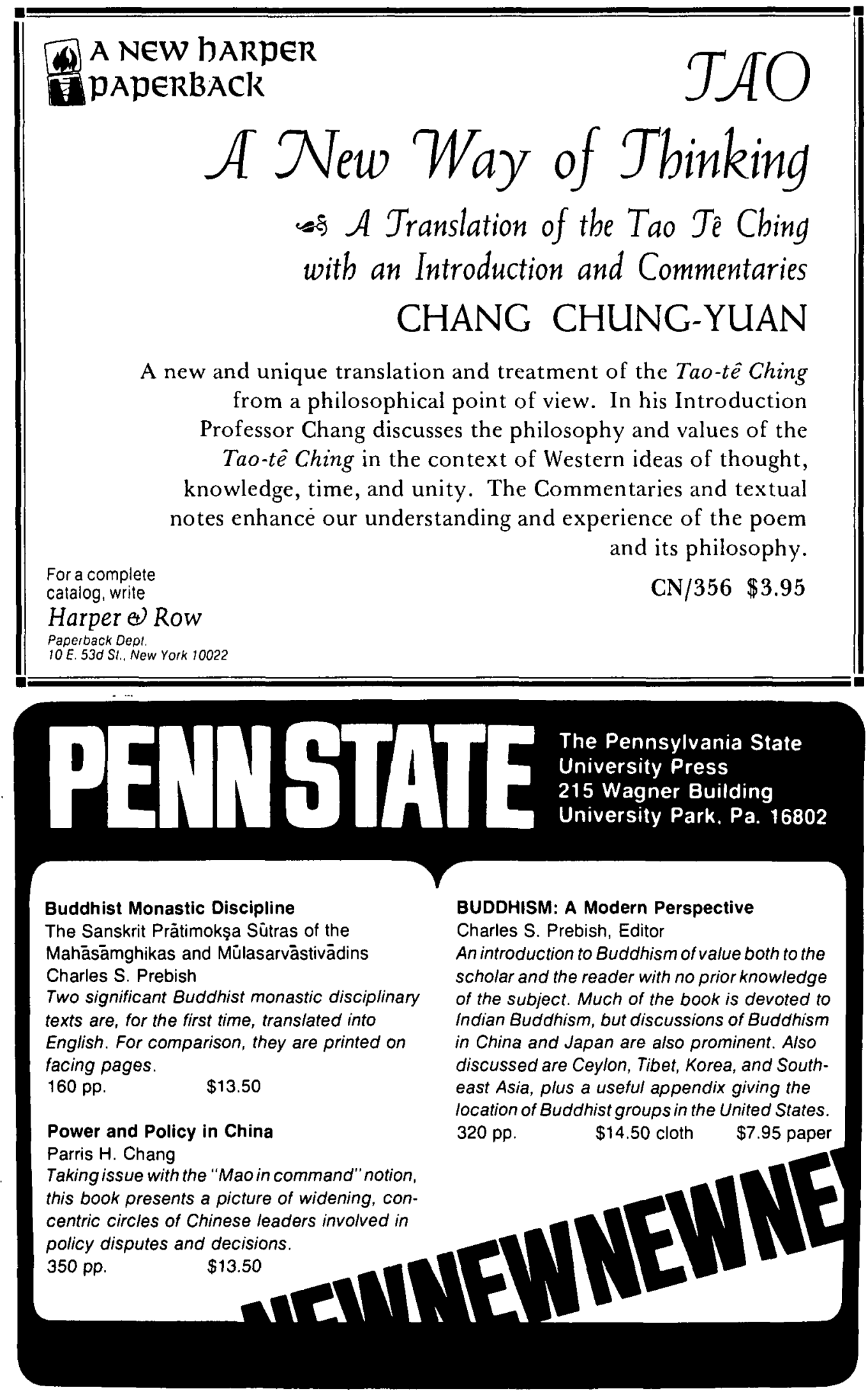


\section{Enduring Scholarship}

The Association's Thirtieth Anniversary Commemorative Series

JOHN A. HARRISON, editor

Outstanding articles selected from

THE FAR EASTERN QUARTERLY - THE JOURNAL OF ASIAN STUDIES

$1941-1971$

\begin{tabular}{|c|c|c|}
\hline CHINA & L. Carringto & bodrich, introductic \\
\hline $\begin{array}{l}\text { H. G. Creel } \\
\text { Röbert M. Hartwell } \\
\text { Edward A. Kracke, Jr. } \\
\text { James T. C. Liu }\end{array}$ & $\begin{array}{l}\text { Jung-pang Lo } \\
\text { Lawrence D. Kessler } \\
\text { Alfred Kuo-liang Ho }\end{array}$ & $\begin{array}{l}\text { Mary C. Wright } \\
\text { Laurence A. Schneider } \\
\text { Donald G. Gillin } \\
\text { David S. Nivison }\end{array}$ \\
\hline
\end{tabular}

Volume 2

JAPAN

Thomas C. Smith Roger F. Hackett Marius B. Jansen Robert S. Schwantes

Bernard S. Silberman
Lawrence D. Kessler

David S. Nivison

\section{Volume 3}

I. Karve

W. Norman Brown

John Brohm

Maurice Freedman

Marjorie Topley

Harry J. Benda

\section{SOUTH \& SOUTHEAST ASIA}

Clifford Geertz, Introduction

Theodore Stern

Norman G. Barrier

Karl J. Pelzer

Rajni Kothari

Rushikesh Maru
Edward C. Dimock, Jr. Lawrence Palmer Briggs M. N. Srinivas J. S. Staal M. C. Ricklefs Karl H. Potter

NON-MEMBERS

Order at $\$ 3.75$ each

from:

THE UNIVERSITY OF ARIZONA PRESS from:

ASSOCIATION FOR ASIAN STUDIES

Box 3398

Tucson, Arizona 85722

Room 1 Lane Hall

University of Michigan

Ann Arbor, Michigan 48104 


\section{5 issue - free on request. Catalog}

\section{ADYAR LBRARY VOLUMES FOR INDIA SPECIALISTS AVALLABLE IN U.S.A.}

Our 1975 Catalog of books in the Adyar Library Series, published by the Adyar Library and Research Centre, Madras, India, is now available free on request. Titles immediately available are grouped under the following subjects:

$\begin{array}{ll}\text { Agama } & \text { Mimamsa } \\ \text { Astrology \& Astronomy } & \text { Music \& Dance } \\ \text { Buddhism } & \text { Nyaya } \\ \text { Ethics, Law, Political Science } & \text { Prakrit Literature } \\ \text { Grammar \& Linguistics } & \text { Poetics \& Dramaturgy } \\ \text { Grihya } & \text { Poetry \& Drama } \\ \text { Gita } & \text { Stotras } \\ \text { Indian Civilization \& Culture } & \text { Upanisads } \\ \text { Lexicography } & \text { Veda } \\ \text { Manuscripts at Adyar-Sanskrit } & \text { and Prakrit. Non-descriptive. } \\ \text { Manuscripts at Adyar-Sanskrit. } & \text { Vedanta } \\ \text { Descriptive. } & \text { Yoga }\end{array}$

Write for free 1975 Catalog of Adyar books to

Theosophical Publishing House, Dept. JAA 306 West Geneva Road

Wheaton, Illinois 60187

PUBLISHERS OF QUEST AND RE-QUEST BOOKS

THE THEOSOPHICAL PUBLISHING HOUSE

WHEATON, IL LONDON MADRAS 


\section{KANSAI GAIDAI \\ (Kansai University of Foreign Studies)}

\section{Study and Living Experience in Japan}

- Wide variety of academic courses on Japan and Asia

- Courses taught by experienced English-speaking Japanese scholars

- Japanese language courses, beginning through advanced levels

- Homestay with Japanese families

- Ideal location: near Kyoto \& Nara (ancient capitals) and Osaka, Japan's industrial metropolis

- Program based at a major university with excellent facilities, library, and research institutes

- Well-established program administered by experienced staff

- Flexible program from three months to one year for groups and individuals

For further information write to:

Office of International Studies

Kansai Gaidai

333 Ogura, Hirakata, Osaka, Japan 573

Tel. (0720) 51-6751 


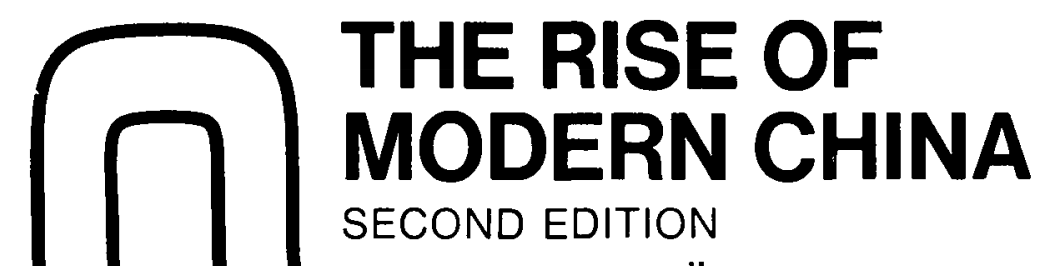

IMMANUEL C. Y. HSÜ, Professor of History, University of
California, Santa Barbara

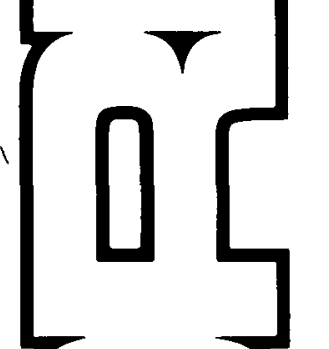

Now in its Second Edition, THE RISE OF MODERN CHINA remains the definitive work on China's transformation from a traditional universal empire to a modern national state. According to Professor Hsü, the history of modern China is essentially a story of the search for a new order that would liberate China from foreign imperialism and domestic disorder and insure her place in the family of nations. These national aspirations have been largely accomplished by the Peking government within twenty-five years of its establishment so that today, China is internally united in the gigantic task of socialist transformation and externally regarded as a superpower destined to be a major shaping force of the world in the decades to come.

In this new edition, Professor Hsü expands and updates his discussion with new material on the Great Proletarian Cultural Revolution; the rise and fall of Lin Piao; the Tenth Party Congress of August, 1973, and its impact on the new power structure; and the Sino-

American Detente and the triangular relations of the United States, the Soviet Union, and China.

\section{From reviews of the First Edition:}

"The most comprehensive history of China yet available... The book is extremely useful to the student in providing him with an up-to-date and fairly detailed bibliography on almost every aspect of modern Chinese history. The value of the bibliography is especially enhanced by the inclusion of many references to the works in Chinese and Japanese."

-W. Allyn Rickett, in The Annals of the American Academy of Political and Social Science

"A masterful work of scholarship tracing political, intellectual, social and economic changes that have affected every phase of Chinese life from 1600 to now and how they were precipitated, to a large degree, by influence from abroad." -Foreign Affairs

"A weighty entry by a leading scholar. [Hsü] has made much use of both Chinese and Western scholarship in constructing this general account of modern Chinese political history, an account overflowing with details and comprehensive in its coverage.... Unique in scope and level of detail."-Ernest P. Young, in Journal of Asian Studies

"A splendid history of modern China... .The book is a comprehensive and carefully documented study; it is a valuable contribution to our understanding of China."-Virginia Quarterly Review

$1975 \quad 1088 \mathrm{pp} . \quad 88$ illus.

$\$ 12.95$ 


\section{U.S. CHINA BUSINESS REVIEW}

A Bimonthly Journal of China's Trade and Economy

Recent issues include Alexander Eckstein on China's economic growth and foreign trade, Audrey Donnithorne on China's foreign. trade system, Dwight Perkins on China's Fourth Five-Year Plan, Dick Wilson on the growing international role of the Bank of China, as well as detailed economic analyses of China's major industrial and agricultural sectors. UCBR emphasizes the practical aspects of doing business with China and reports comprehensively on Peking's buying and selling patterns both in the US and worldwide.

University and Municipal Libraries $\$ 50.00$ per year

Individuals $\$ 60.00$ per year-Add $\$ 15.00$ outside of Canada and US

Published by

The National Council for U.S.-China Trade

1100 Seventeenth Street, N.W.

Washington, D.C. 20036

\section{ANNOUNCEMENT}

The Twenty-eighth Annual Meeting of the Association for Asian Studies will be held at the Royal York Hotel, Toronto, Canada, March 19-21, 1976.

The Twenty-ninth Annual Meeting of the Association for Asian Studies will be held at the Waldorf-Astoria Hotel, New York City, March 25-27, 1977. 

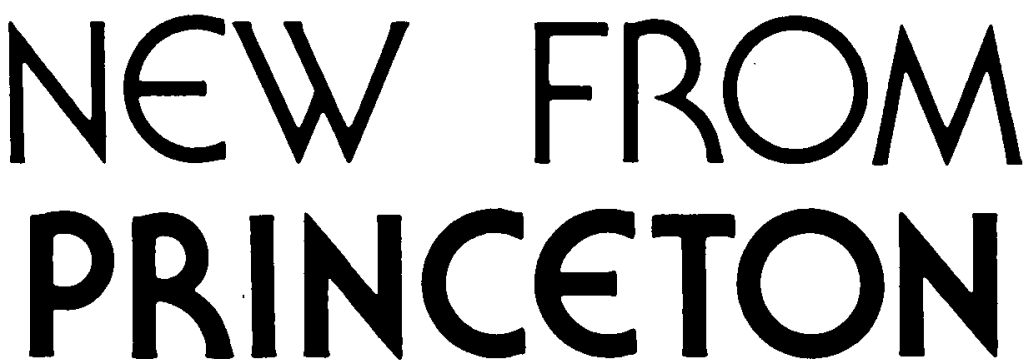

FESTIVALS IN

CLASSICAL CHINA

New Year and Other Annual

Observances during the

Han Dynasty

(206 B.C.-A.D. 220)

DERK BODDE

In a unique study of the annual lunar and solar New Year festivals and other yearly observances celebrated 2000 years ago in China, Derk Bodde develops a broad spectrum of the cosmological conceptions, religious and magical beliefs, and court life and folk practices of the classical Chinese. $\$ 17.50$

\section{7th Edition}

\section{IRAN}

\section{Past and Present}

DONALD N. WILBER

Long recognized as the standard work on Iran, this book has been completely revised to update statistics and to include current information on the country's history. "The best short summary of Iran's two and a half millennia of history yet to appear in print." -Midd/e East Journal $\$ 17.50$

\section{STUDIES IN THE}

\section{INTELLECTUAL HISTORY} OF TOKUGAWA JAPAN MASAO MARUYAMA

Translated by MIKISO HANE

This is the first English translation of Masao Maruyama's most important work, originally published in Japan in 1952. A comprehensive study of changing political thought during the Tokugawa period, the book traces the philosophical roots of Japanese modernization. $\$ 15.00$

\section{THE GOLDEN AGE OF CHINESE DRAMA Yüan Tsa-chì CHUNG-WEN SHIH}

The 171 extant plays of the Yüan period (1279-1368) are the oldest and most brilliant examples of Chinese dramatic literature. In this first comprehensive study, Chung-wen Shih systematically explores the riches of Yiuan drama, from its unexcelled lyric poetry to its colorful characterization. $\$ 16.50$

\section{THE MYTHIC IMAGE ofo JOSEPH CAMPBELL}

An imaginative journey though the mythology of the world's high civiliza. tions, featuring Joseph Campbell's distinguished narrative and 432 illustrations of mythic art from Oriental and Occidental cultures. "An iconography of the human spirit."-Peter S. Prescott, Newsweek

Bollingen Series C $\bullet 9 \times 12 " \bullet 432$ illus., 32 in color

$\$ 45.00$ Deluxe boxed, signed, and numbered edition, $\$ 100.00$

\section{PEASANTS, POLITICS, AND REVOLUTION}

Pressures toward Political and Social Change in the Third World JOEL S. MIGDAL

Drawing on various sources, the author shows that material incentives rather than ideological fervor induce peasants in Latin America and Asia to leave their villages for political activity or sustained revolution. $\$ 15.00$

Order from your bookstore or direct from

\section{PRINCETON}

UNIVERSITY PRESS

Princeton, New Jersey 08540 


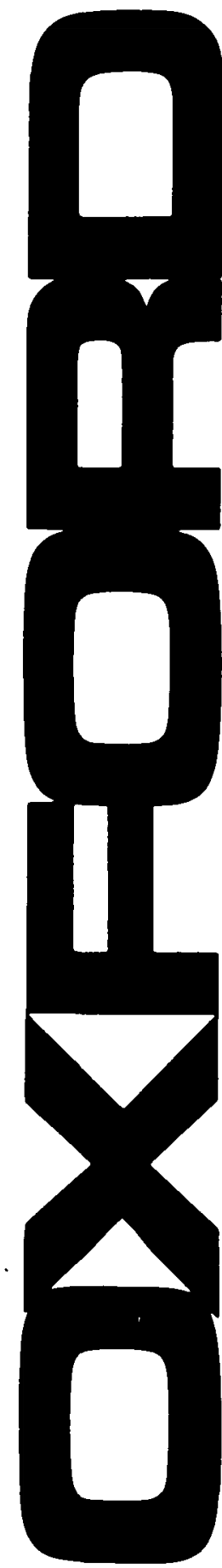

\section{Japan's Greater East Asia Co-Prosperity Sphere} in World War II

Edited with an introduction by JOYCE C. LEBRA, University of Colorado. Combining both Western articles and translations of Japanese papers on Japan's sphere of influence, this volume makes available recent scholarship on a subject which had been long avoided in both the East and the West. In her introduction, the editor offers an outline of Asian and Western scholarship on Japanese wartime activities. $1975 \quad 234 \mathrm{pp} \quad \$ 21.75$

\section{The Kuril Islands}

Russo-Japanese Frontiers in the Pacific

JOHN J. STEPHAN, University of Hawaii. Suspended along Asia's northeastern rim, the Kuril Islands have been a meeting ground for diverse peoples and cultures since prehistoric times. In recent times the rival claims of Russia and Japan for the islands have involved the United States and the People's Republic of China. Based on multi-national sources, including recently declassified documentary material, this is the first comprehensive study of the area.
1975
256 pp.; 5 maps; plates
$\$ 20.00$

\section{Konfrontasi}

The Indonesia-Malaysia Dispute 1963-1966

J. A. C. MACKIE. Indonesia's confrontation with Malaysia in the sixties was less than a war, but something more than a mere diplomatic dispute. The author analyzes the causes of the confrontation in relation to the political climate of Indonesia, while maintaining a balance between the Indonesian sides of the story and tracing the interaction of domestic and international developments in both countries.

$1975 \quad 384$ pp.; 5 tables; maps $\$ 26.00$

\section{The Politics of Belonging}

Political Change in Sabah and Sarawak

MARGARET CLARK ROFF, City University of New York. Sabah and Sarawak gained independence from Great Britain in 1963 with the formation of Malaysia. This study is concerned with developments in these two Bornean states since then. The portrayal of political mobilization, the rapid establishment of political parties, and the emergence of new leaders, will be of interest to scholars in a variety of disciplines, and to those concerned with the problems of incorporating fringe groups and minorities into modern states. (East Asian Historical Monographs)
1975
$210 \mathrm{pp}$.
$\$ 16.00$

\section{Imperial Britain in South-East Asia}

NICHOLAS TARLING. A number of Professor Tarling's papers on nineteenth-century British policy in Southeast Asia have been revised and collected in this volume. The essays deal with the Malaysian region, Thailand, Vietnam, Cambodia, and the Andaman and Nicobar Islands; they analyze the significance of British policy decisions, and highlight the colorful personalities of such men as Stamford Raffles and James Brooke.
1975
286 pp.; 7 plates
$\$ 21.75$

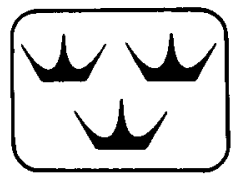




\title{
ORIENTAL THOUGHT
}

An Introduction to the Philosophical and Religious Thought of Asia

by

\section{Yong Choon Kim}

\author{
University of Rhode Island, Kingston, Rhode Island
}

With a Foreword by David H. Freeman

In recent years the West has become curious about Eastern thought and has directed more attention to it. Knowledge of the ideas and beliefs of other peoples is essential for the civilized man; therefore, this book will be most informative to Western readers. The purpose of this book is to provide a basic introduction to the philosophical and religious ideas of the East. The approach is analytical, comparative, and critical. It deals with the major areas of Oriental thought: Hinduism and Buddhism in India; Confucianism, Taoism and Neo-Confucianism in China; Shamanism, Buddhism, Confucianism and Ch'ondogyo in Korea; Shinto and Buddhism in Japan. Written for those beginning the study of Oriental philosophy or Eastern religions, this book will be useful not only to introductory level students in universities and colleges, but also to the general reader who is interested in Oriental thought and culture. "... his discussions of main concepts of each religious and philosophical tradition of the East are penetrating and full of insights into the essence of each tradition."-Doctor Chin Sei Yu, Goddard College, Plainfield, Vermont.

144 pp., cloth-\$8.75, paper-\$5.95

\section{CHARLES C THOMAS • PUBLISHER

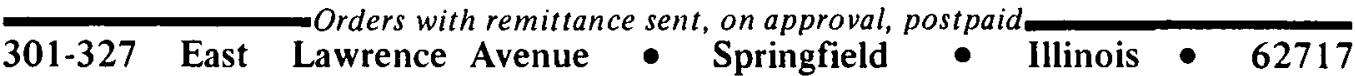

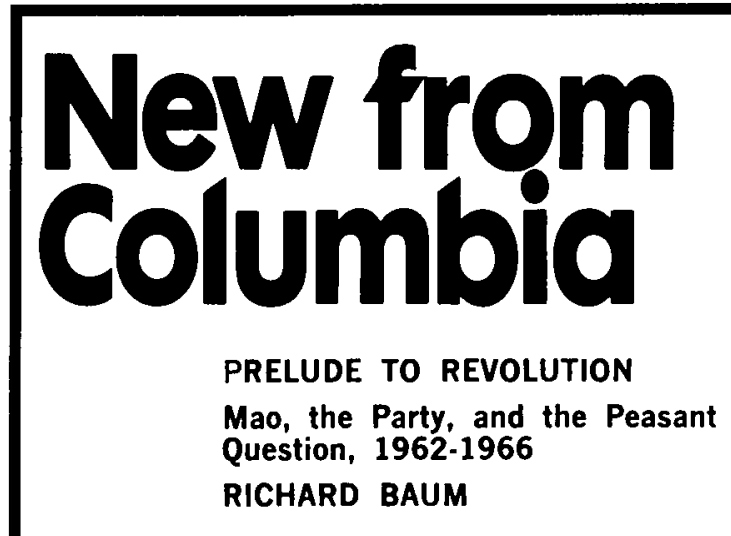

Providing new insights into a par. ticularly confusing historical period, Richard Baum, in his new book, discusses the origins of the Great Proletarian Revolution in three interrelated areas: the conflicts between Mao Tse-Tung and his chief lieutenants, the Socialist Education Move. ment, and the state and rural party administrations. $\$ 10.00$

\section{CULTURES IN CONFLICT}

The Four Faces of Indian Bureaucracy

\section{STANLEY J. HEGINBOTHAM}

Based on extensive interviews and sophisticated questionnaire surveys, Professor Heginbotham reveals the complex of cultural, historic, and ideological forces acting upon bureaucracies in India. This important new study reveals not only the struc. ture of modern Indian bureaucracy but also the details of that life and style.

$\$ 12.50$

\section{COLUMBIA UNIVERSITY PRESS}




\section{INSIGHTS FROM THE EAST}

\section{Fiction}

\section{THE SILENT CRY by Kenzaburo Oe}

Translated by John Bester. This daring, powerful novel by Japan's first truly modern writer skillfully blends thought and extremes of action (including adultery, mob violence and suicide) into the story of a Japanese family in search of its identity. Within the context of past and present, Oe examines a wide range of contemporary problems. "Kenzaburo Oe has reached a new pinnacle in postwar Japanese fiction." - Yukio Mishima. "Oe seems to me to have in him a touch of Dostoevsky."-Henry Miller. Awarded the Tanizaki Prize. \$10.00 Just Published

\section{THE WAITING YEARS by Fumiko Enchi}

Translated by John Bester. Brilliantly etched scenes of human and domestic interplay illuminate this classic novel of life in Japan before the war. Rooted deep in female psychology, it combines a spare style that echoes the Tale of Genji with an acute sense of realism and character. The keen insight of its author, Japan's leading' novelist and a member of the prestigious Art Academy, accents

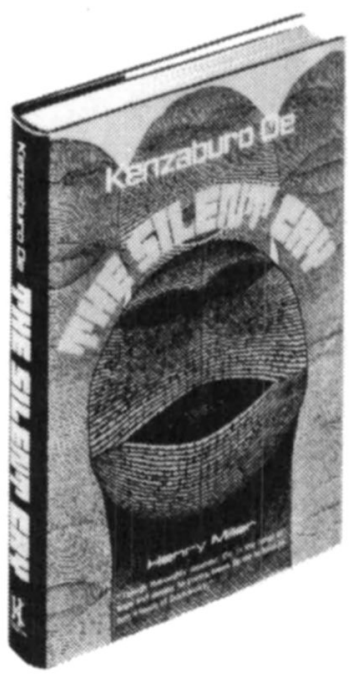
more clearly than any other work of fiction the social mores of this era and their effects upon a particular family. Awarded the Noma Prize. $\$ 7.95$ 


\section{KODANSHA INTERNATIONAL}

\section{Poetry and Song}

\section{A HAIKU JOURNEY}

Bashō's The Narrow Road to the Far North and Selected Haiku

Photographs by Dennis Stock; translated and introduced by Dorothy Britton. In the 17th century the pilgrim-poet Bashō trekked throughout most of Japan, recording his impressions in prosepoetry diaries. The most famous of these now appear in a new and sensitive translation, accompanied. by magnificent full-color photographs that give an extraordinary visual dimension to the

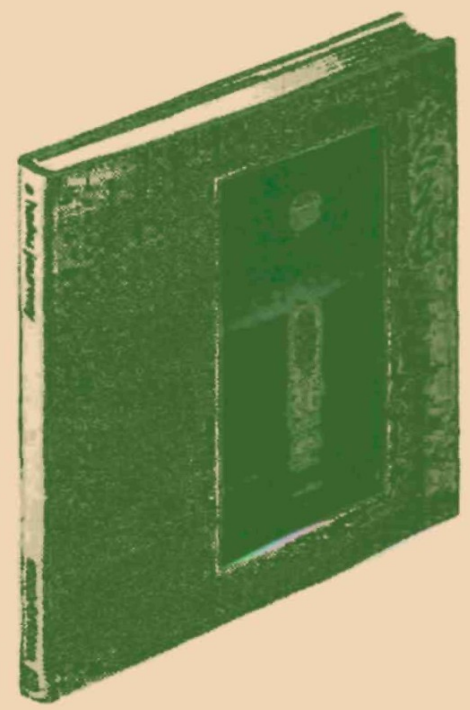
poet's images and insights. The combination of these art forms for the first time makes this a memorable book. $111 / 2^{\prime \prime} \times 111 / 2^{\prime \prime}$ Deluxe Binding $\mathbf{5 1 7 . 5 0}$ Just Published

\section{THE SILENT FIREFLY} Japanese Songs of Love and Other Things

Translated by Eric Sackheim. Collected from all parts of Japan, these short popular songs or minyo express an ancient folk culture in immediate, personal terms. Most are love songs, but there are also work songs, farming and fishing songs,

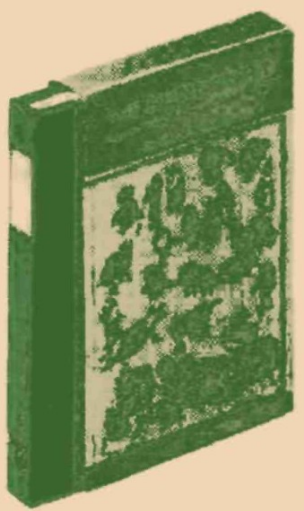
lullabies and songs for festivals. Their influence on modern Japanese song and poetry has been considerable; and their appeal to the modern reader is enhanced by 32 full-page color illustrations from an early woodblock artist's copy book. Boxed. $\mathbf{\$ 7 . 5 0}$

At bookstores or direct from the publisher 


\title{
Soutb Asia
}

\section{RURAL DEVELOPMENT IN BANGLADESH AND PAKISTAN}

\author{
edited by Robert D. Stevens, Hamza Alavi, and Peter J. Bertocci
}

The first in-depth treatment of the progress of rural development in the two areas that formerly comprised the nation of Pakistan. By evaluating the results of various strategies connected with this area's "green revolution" within the context of economic and social change, these studies provide insights into the mechanisms of the developmental process in emerging nations.

AN EAST-WEST CENTER BOOK 王

$\$ 15.00$

\section{ENCOUNTER AND EXPERIENCE: Personal Accounts of Fieldwork edited by André Beteille and T.N. Madan}

Twelve essays on the problems and rewards of personal experience in fieldwork by Indian, Japanese, British, and American anthropologists and sociologists working mainly in India (one among the Zuni Indians of North America). An introduction discusses the central role of fieldwork in anthropology, the development of methods from nineteenth-century "armchair scholarship" to modern "participant-observation," advocating the need for a balance between subjectivity and objectivity in interpreting data. $\$ \mathbf{\$ 8 . 0 0}$

\section{ESSAYS ON SOUTH INDIA}

\section{edited by Burton Stein}

Covering a broad spectrum of knowledge and time-from archaeology to sociology, and from the Early Stone Age to the present-the authors conveniently summarize what Asian and Western scholars have learned about the history and culture of an important region of the Indian subcontinent. Against this background, several of the authors perceptively discuss particular situations in which forces for change are interacting with a set of social, political, and cultural traditions that are both venerable and highly complex. (Asian Studies at Hawaii, No. 15)

paper, $\$ 8.50$

\section{THE UNIVERSITY PRESS OF HAWAII}

Honolulu, Hawaii 96822 